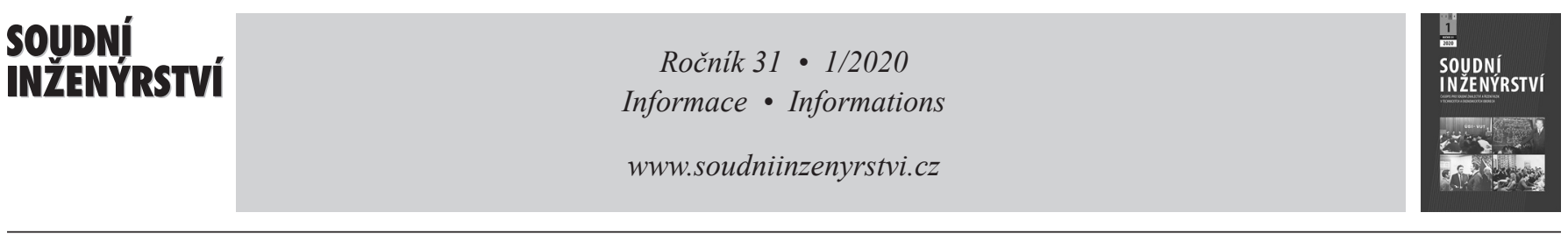

\title{
Z historie Ústavu soudního inženýrství Vysokého učení technického v Brně
}

\author{
From the History of the Institute of Forensic Engineering, Brno University of Technology
}

Albert Bradáč ${ }^{*}$ emeritní profesor

Vedením Ústavu soudního inženýrství Vysokého učení technického v Brně jsem byl jako nejstarší pamětník požádán o osobní vzpomínky na začátky a další vývoj ústavu.

Počátek činnosti ústavu je spojen zejména se jménem jeho prvního ředitele, zakladatele vědeckého pojetí technické soudní expertízy a neúnavného učitele, pana Ing. Jiřího Smrčka (30. 12. 1906 13. 6. 1987) ${ }^{1)}$. Byl synem pana prof. Ing. Antonína Smrčka, dr.h.c., rádného profesora vodního stavitelství na brněnské technice, který v letech 1913-1914 zastával funkci jejího rektora. Ing. Smrček vystudoval strojní inženýrství, podle jeho vyprávění se specializací pro parní lokomotivy. Již jako student se za měsíční paušál staral bohatším o stálou pojízdnost jejich osobních automobilů (vyprávěl, jak při mrazech nosil s sebou lahvičku éteru do sání pro lepší startování, nebo když se řidiči nechtělo ve sněhu nebo blátě měnit defektní kolo, tak musel nastoupit on, a že těch hřebíků z podkov na silnicích bylo tehdy hodně). Byl soudním znalcem, úředně oprávněným civilním inženýrem.

Za německé okupace byl pan inženýr Smrček členem odbojové organizace Obrana národa, jejíž členové bohužel byli brzy gestapem odhaleni; měl jsem možnost číst dopis jeho advokáta panu profesoru Smrčkovi, že je to výborné, u Volksgerichtu v Berlíně jeho syn dostal jenom pět let vězení(!). Pan inženýr Smrček vyprávěl, že se mu vyplatila znalost němčiny; nepřiznal ji, a pak při výslechu u soudu než tlumočník přeložil otázku, mohl si připravit odpověd', takže to vypadalo věrohodněji. $V$ rámci věznění pracoval ve výrobě protiletadlových čtyřkulometů; po vypršení trestu byl totálně nasazen na totéž místo. Po dobytí města americkou armádou byl dokonce civilním velitelem města a dohlížel na rozdělování potravin. Po válce byl vyznamenán mj. Československým válečným křrižem, vojenskou medailí za zásluhy I. stupně, za činnost na ÚSI pak zlatou medailí VUT v Brně. Svými zásluhami v odboji se přitom nikdy nechlubil, ani je neuplatňoval.

Zákonem č. 47/1959 Sb., o úpravě právních poměrů znalců a tlumočníků, spolu s prováděcí vyhláškou č. 193 Ú.1., byly dle

1) https://encyklopedie.brna.cz/home-mmb/?acc=profil_osobnosti\&load=2702

Dodáno do redakce: 20. 2. 2020

Recenzní řizení: nepodléhá recenzi důvodové zprávy „,vymýceny soukromo-podnikatelské způsoby při provádění znaleckých a tlumočnických úkonů“. Byli zrušení soudní znalci jako jedni z posledních živnostníků a dožadující orgány požadovaly od orgánů státní správy a organizací socialistického sektoru, aby jim byla označena osoba, která má provést znalecký úkon. V té době pan inženýr Smrček pracoval v národním podniku Průmyslové stavby Gottwaldov a souběžně podával znalecké posudky. $\mathrm{V}$ rámci této činnosti byl pověřen vypracovat posudek silniční nehody blízko Veverské Bítýšky, kdy nákladnímu vozidlu Garant praskla levá přední pneumatika a najelo do protisměru, kde jel osobní automobil Tatra 603, v němž byli těžce zraněni řidič a prorektoři VUT. Měl jsem možnost vidět fotografie poškozené tatry; při pohledu zprava vypadala jako nová, ale levá polovina byla zdeformovaná po celé délce (bohužel, snímek se v archivu ÚSI nedochoval).

Když si znalecký posudek pana inženýra Smrčka přečetl tehdejší rektor VUT prof. Ing. arch. Vladimír Meduna, dr. h. c., pozval si autora posudku s tím, že je to inženýrské dílo a že by se metodika znalecké analýzy nehod měla vyučovat na vysoké škole. Domluvili se a jako první krok se pan Ing. Smrček stal odborným asistentem strojní fakulty VUT, katedry spalovacích motorů a motorových vozidel.

Jedním z posudků, jehož zpracováním byl na katedře pověřen, byla podle vyprávění Ing. Smrčka nehoda zkušebního vozidla Tatra 603 s továrním řidičem výrobce, kdy po přejezdu železničního prejezdu tatra narazila do protijedoucího vozidla; nehoda měla smrtelné následky. Tehdejší děkan strojní fakulty a současně vedoucí katedry, jenž měl úzké vztahy s národním podnikem Tatra, přesvědčoval zpracovatele posudku, aby z toho řidič tatry vyvázl bez zavinění. Zpracovatelé tento pokus o ovlivňování uvedli do znaleckého posudku; výsledkem bylo disciplinární rízení děkana (nevím bohužel, jestli pracovní nebo stranické) a rozhodnutí rektora přenést soudní inženýrství z fakulty na rektorát. (Uvědomil jsem si při psaní této věty, že pan Ing. Smrček nebyl nikdy členem žádné politické strany; prohlašoval, že je příslušníkem strany technické a řídí se fyzikálními zákony, jež nepodléhají politickým ani jiným vlivům). 
Autor tohoto vyprávění na ústav nastoupil k 1. prosinci 1969; byla to přitom souhra náhod. Pan inženýr Smrček byl v době svých studií členem výboru Akademického čtenářského spolku Zora, kde $\mathrm{v}$ rámci této funkce se podílel mj. na organizaci plesů; tam se také seznámili s mojí maminkou. Náhodou se po mnoha letech potkali, pan inženýr Smrček se pochlubil, že se zakládá ústav soudního inženýrství a že byl právě vypsán konkurz na odborného pracovníka.

Byli jsme tehdy na oddělení soudního inženýrství rektorátu tři; pan inženýr Smrček jako vedoucí, sekretářka slečna Marie Marešová a autor jako odborný pracovník; o zpracování posudků byl vedoucí pracoviště oprávněn požádat kohokoli z VUT. Sídlo bylo v tehdejší budově rektorátu na Opletalově ulici č. 6 (po restitucích nyní farní úřad tzv. Červeného kostela). Obsahem našich pravidelných denních pohovorů nad ranní kávou byly mimo jiné posudky, jež byly zpracovány před autorovým příchodem na ústav. Jedním z nich byly příčiny smrtelných výbuchů několika parních lokomotiv ve stoupání na trati z Brna směr Žd'ár nad Sázavou. Jednalo se o lokomotivy těžkotonážních vlaků, modernizované z vytápění uhlím na automatické vytápění mazutem. Jak bylo zjištěno, vytápění mazutem poskytovalo oproti uhlí až dvojnásobný výkon; při plném výkonu ve stoupání došlo k tak velkému odpařování vody, že ji stávající čerpadla nestačila doplňovat, obnažila se plocha kotle ve styku s plamenem, materiál se přehřál a kotel vybuchl.

Další bylo zjišt'ování prríčiny havárie elektrické lokomotivy na střídavý proud, která při zajíždění do depa Brno-Maloměřice najednou začala místo snižování samovolně zvyšovat rychlost; strojvůdce se snažil zachránit vyskočením z lokomotivy, ale setrvačností narazil do zdi depa a byl na místě mrtev, takže nemohl popsat příčiny zrychlování. Lokomotiva narazila do další lokomotivy stojící v depu, která vyrazila další ven. Byla zde řada domněnek o př́čině, nakonec se podařilo dokázat, že se jednalo o výrobní vadu lokomotivy; stejných lokomotiv řada ovšem byla dodána po celé Evropě.

Popsáno laicky má tato lokomotiva na stanovišti strojvedoucího pro ovládání rychlosti něco jako čtvrtinovou výseč volantu, jež se od rovnovážné polohy uprostřed může pohybovat o dvě polohy doleva a o dvě doprava. První stupeň na jednu stranu znamená přidat o jednu odbočku na regulačním transformátoru, pro další odbočku je nutno zpět na nulu a opakovat. Druhý stupeň na stejnou stranu má za následek automatické přidávání (pokud si pamatuji, asi o dvě odbočky za sekundu). Na druhou stranu je to obráceně první stupeň znamená ubrat o jednu odbočku, druhý stupeň ubírat postupně automaticky. Na ose tohoto ,volantu“ je dole v kontroleru převod šikmým ozubením na hřídel s vačkami, zajišt'ujícími požadované úkony; na rozmezí od jedné krajní polohy „volantu“ do druhé připadala jedna otočka hřídele s vačkami. A zde byl právě problém: kola ozubení se na hř́ídeli svrtávala při montáži. $V$ daném případě došlo přitom bohužel k nepatrnému pootočení tak, že bylo možno dojít ještě za druhý stupeň, určený pro automatické snižování, regulace tam skočila jakoby dokola na druhý stupeň zrychlování, což pak způsobilo nehodu. Následně se pak snad prý asi šedesát těchto lokomotiv v Evropě opravovalo.

Příště další zajímavé př́ípady.

\section{Správná citace:}

BRADÁČ, A. Z historie Ústavu soudního inženýrství Vysokého učení technického v Brně Soudní inženýrství, 2020, 31(1), 35-36.

DOI: http://dx.doi.org./10.13164/SI.2020.1.35. ISSN 1211-443X. 